\title{
Update on SLC6A14 in lung and gastrointestinal physiology and physiopathology: focus on cystic fibrosis
}

\author{
Manon Ruffin $^{1}$ (1) - Julia Mercier ${ }^{1}$. Claire Calmel ${ }^{1}$. Julie Mésinèle ${ }^{1} \cdot$ Jeanne Bigot $^{1}$ - Erika N. Sutanto ${ }^{2,3}$. \\ Anthony Kicic ${ }^{2,3,4,5}$ (D) Harriet Corvol ${ }^{1,6}$ (D) $\cdot$ Loic Guillot $^{1}(\mathbb{C}$
}

Received: 28 November 2019 / Revised: 24 January 2020 / Accepted: 17 February 2020 / Published online: 12 March 2020

(c) The Author(s) 2020

\begin{abstract}
The solute carrier family 6 member 14 (SLC6A14) protein imports and concentrates all neutral amino acids as well as the two cationic acids lysine and arginine into the cytoplasm of different cell types. Primarily described as involved in several cancer and colonic diseases physiopathological mechanisms, the SLC6A14 gene has been more recently identified as a genetic modifier of cystic fibrosis (CF) disease severity. It was indeed shown to have a pleiotropic effect, modulating meconium ileus occurrence, lung disease severity, and precocity of $P$. aeruginosa airway infection. The biological mechanisms explaining the impact of SLC6A14 on intestinal and lung phenotypes of CF patients are starting to be elucidated. This review focuses on SLC6A14 in lung and gastrointestinal physiology and physiopathology, especially its involvement in the pathophysiology of CF disease.
\end{abstract}

Keywords $\mathrm{ATB}^{0,+} \cdot$ Amino acid transporter $\cdot \mathrm{CFTR} \cdot$ Nitric oxide $\cdot$ Pulmonary $\cdot$ Intestine

\section{Introduction}

Cystic fibrosis $(\mathrm{CF})$, the most common lethal autosomal recessive genetic disease in Caucasians, is caused by variants in the gene encoding the cystic fibrosis transmembrane

Manon Ruffin and Julia Mercier have contributed equally to this work as co-first authors.

Harriet Corvol

harriet.corvol@aphp.fr

1 Sorbonne Université, INSERM UMR S 938, Centre de Recherche Saint-Antoine (CRSA), Paris, France

2 Telethon Kids Institute, University of Western Australia, Nedlands, WA, Australia

3 School of Public Health, Curtin University, Bentley, WA, Australia

4 Centre for Cell Therapy and Regenerative Medicine, Medical School, The University of Western Australia, Nedlands, WA, Australia

5 Department of Respiratory and Sleep Medicine, Perth Children's Hospital, Nedlands, WA, Australia

6 Pneumologie Pédiatrique, APHP, Hôpital Trousseau, Paris, France conductance regulator (CFTR), a chloride channel expressed ubiquitously within epithelia [1-3].

Symptoms can occur as early as birth with meconium ileus (MI), a severe neonatal intestinal obstruction affecting around $15 \%$ of CF neonates. This is followed by manifestations of the disease in other organs such as the liver, the pancreas, and the intestine, with lung complications as the main cause of morbidity and mortality in CF patients. In the lungs, absence or dysfunction of CFTR proteins results in altered salt and water transport through the airway epithelium leading to an altered mucociliary clearance, progressive colonization with different pathogens, exacerbation of inflammation, and lung tissue damage. Among the multitude of pathogens colonizing the CF lungs, Pseudomonas aeruginosa is the most common and life-threatening pathogen. Indeed, $P$. aeruginosa chronic lung colonization has been associated with a more severe lung disease and reduced survival [4].

Although CF is a monogenic disease, considerable phenotypic diversity is observed in patients carrying identical CFTR variants [5-7]. In addition to environmental factors, twins and siblings' studies have revealed that genetic modifiers outside the CFTR locus are involved in this interindividual variability [5]. It is expected that these modifier genes account for $50 \%$ of the lung function variation. The current 
challenge is to identify these variants and determine how they contribute to the severity of the disease by performing in vitro/in vivo functional studies. Among the several modifier genes identified thus far, the solute carrier family 6 member 14 (SLC6A14, also known as $A T B^{0,+}$ ) has been shown to have pleiotropic effect in CF [8-14]. It was first identified as a modifier of MI occurrence [14], and then associated with lung disease and age at first $P$. aeruginosa infection $[8$, 10]. SLC6A14, the protein encoded by this gene, belongs to the solute carrier family 6 and uses the energy provided by $\mathrm{Na}^{+}$and $\mathrm{Cl}^{-}$gradients to import and concentrate all neutral amino acids as well as the two cationic acids lysine and arginine into the cytoplasm of different cell types. Besides the genotype/phenotype associations, the biological mechanisms explaining the impact of SLC6A14 on intestinal and lung phenotypes of $\mathrm{CF}$ patients are beginning to be elucidated as evidenced by recent studies [15-17]. This review focuses on SLC6A14 in the context of CF, especially its involvement in the pathophysiology of CF lung and gastrointestinal disease.

\section{SLC6A14 expression and regulation in the lung and gastrointestinal tract}

SLC6A14 gene is located on chromosome $\mathrm{X}$ and was cloned in 1999 from a mammary gland cDNA library [18]. This gene produces two transcripts (ENST00000598581.3 and ENST00000463626.1) but only one codes for a protein (ENSG00000087916.7) which is comprised of 642 amino acids with an expected molecular weight of $72 \mathrm{kDa}$. SLC6A14 is a plasma membrane protein belonging to the solute carrier 6 (SLC6) family which contains 21 human proteins based on the similarity in their amino acid sequences [19]. Although no structural studies have been conducted on SLC6A14 specifically, crystal structure and structural studies on others members of the SLC6 family, as well as topological domain analysis (https://uniprot.org/ uniprot/Q9UN76) suggest that SLC6A14 N- and C-terminal domains are cytoplasmic and that the sequence includes 12 putative transmembrane domains and 1 large extracellular domain between transmembrane domains 3 and 4 [19]. In the endoplasmic reticulum, the quality control of SLC6A14 folding involves interactions with the heat shock proteins HSP70 and HSP90 [20]. SLC6A14 trafficking from the endoplasmic reticulum to the Golgi apparatus depends on its interaction with the cargo-recognizing protein SEC24 isoform $\mathrm{C}$ and the coatomer II (COPII) complex [21]. Further studies are needed to fully understand the mechanisms allowing SLC6A14 trafficking to the plasma membrane.

SLC6A14 mRNA was initially shown to be expressed mainly in the lung, fetal lung, trachea, and salivary gland [18]. Microarray and RNA-sequencing data obtained from Expression Atlas public resource confirm that SLC6A14 is predominantly expressed in human and mouse lung tissue (Table 1). However, SLC6A14 is also detected albeit in extremely low levels in gastrointestinal tissues including intestine and colon.

\section{SLC6A14 expression and regulation in the lung}

Before SLC6A14 mRNA and protein were identified in the human lung, Galietta et al. demonstrated the presence of a $\mathrm{Na}^{+}$-dependent amino acid transport at the apical membrane of bronchial epithelial cells isolated from CF or non-CF subjects [32]. Upon showing that SLC6A14 mRNA was strongly expressed in the human lung and trachea compared to other organs [18], Sloan et al. also showed that SLC6A14 protein was expressed in membrane fractions of human airway and distal lung samples from normal, emphysema, and $\mathrm{CF}$ patients [33]. Interestingly, the authors pointed out differences in the molecular mass of SLC6A14 protein detected either in the airways or in the distal lung, which was due to alternative splicing or posttranslational modification. Several studies have also shown expression of SLC6A14 in various cell lines of either airway or distal epithelial cell origin, as well as in primary bronchial epithelial cells (Table 2). In the alveolar A549 cell line, SLC6A14 protein was either detected or absent according to the study considered [34, 35]. Di Paola et al. observed that primary cells from individuals with $\mathrm{CF}$ or healthy donors showed a similar mRNA level for SLC6A14 [17], suggesting that CFTR pathogenic variants had no impact on SLC6A14 mRNA expression. Interestingly, a recent study using single RNA sequencing revealed that $S L C 6 A 14$ expression was reduced in alveolar type II cells from idiopathic pulmonary fibrosis (IPF) patients compared to controls [36]. Via single-cell analysis, the authors also showed that SLC6A14 was expressed in basal, club cells, and alveolar type 2 cells.

In vitro, Gorrieri et al. observed that SLC6A14 transcripts were enhanced in bronchial epithelial cells exposed to interleukin-4 [39]. In the human glandular bronchial epithelial cell line Calu-3 and in primary human bronchial epithelial cells, flagellin or lipopolysaccharide from $P$. aeruginosa exposures increase the expression of SLC6A14 mRNA [17]. Finally, in relation to CF, a study using HEK-293 cells overexpressing SLC6A14 showed that SLC6A14 protein expression was reduced by suprapharmacological concentrations of Vx-770, a CFTR potentiator [40].

\section{SLC6A14 expression and regulation in the gastrointestinal tract}

In the human gastrointestinal tract, SLC6A14 appears to be heterogeneously expressed (Table 3). Sloan et al. first detected SLC6A14 mRNA in the stomach, although its levels were significantly lower than those observed in lung samples 


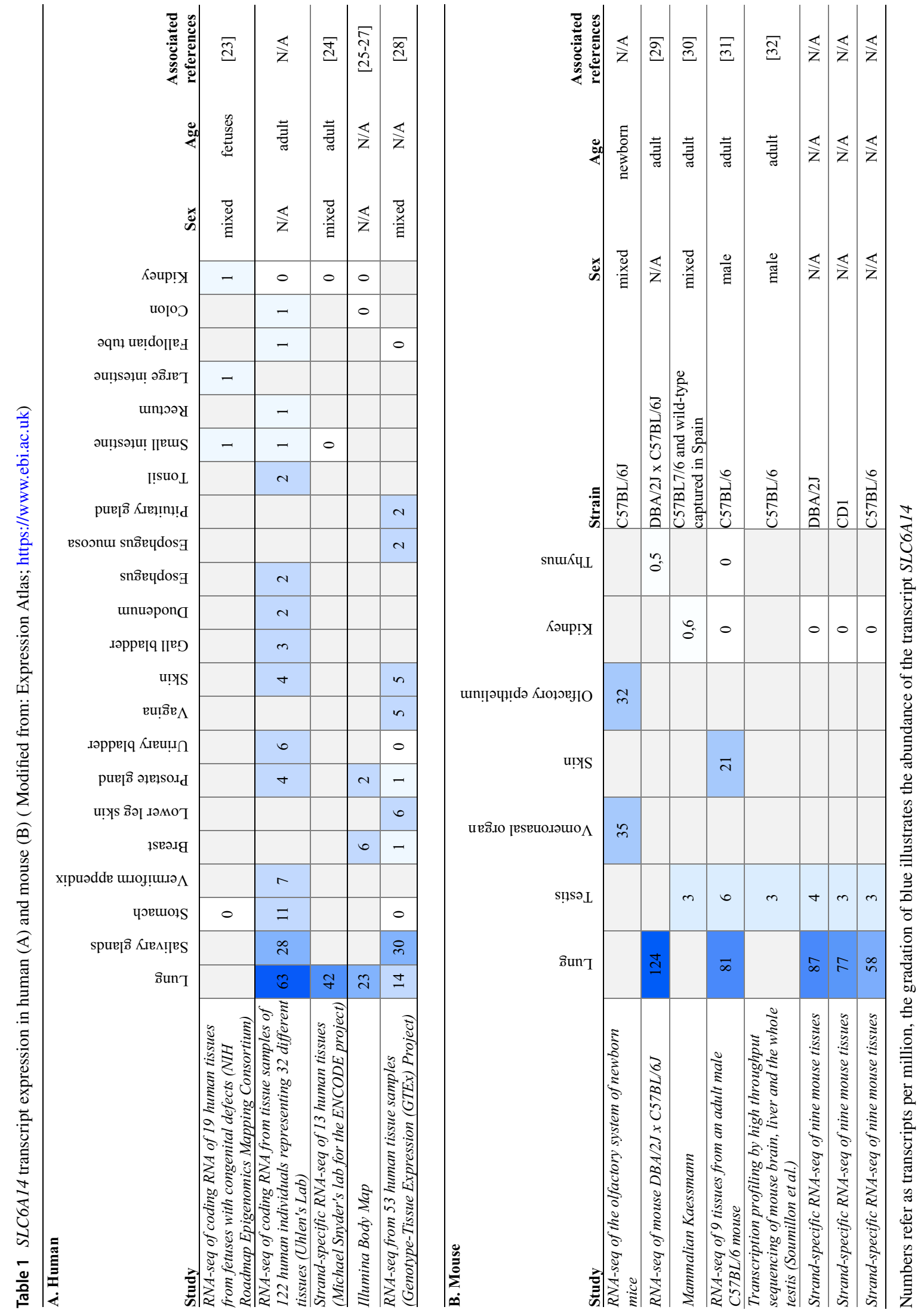


Table 2 Expression of SLC6A14 at the mRNA and protein levels in the human respiratory tract
Table 3 Expression of SLC6A14 at the mRNA and protein level in human gastrointestinal tract

\begin{tabular}{lllll}
\hline Sample & Tissue/cell types & mRNA & Protein & Ref \\
\hline Tissues & Lung tissue samples & & Expressed (WB) & {$[33]$} \\
Cell lines & Calu-3 & Expressed (qPCR) & - & {$[37]$} \\
& NCI-H69 & Expressed (qPCR) & - & {$[38]$} \\
& A549, BEAS-2B & Barely detectable (qPCR) & Undetected (WB) & {$[34]$} \\
& Calu-3, NCI-H441 & Expressed (qPCR) & Expressed (WB) & {$[34]$} \\
& Calu-3, CFBE41o- & Expressed (qPCR) & - & {$[17]$} \\
& A549 & - & Expressed (WB) & {$[35]$} \\
Primary cells & Alveolar type 2 cells isolated & Expressed. Reduced in IPF & - & {$[36]$} \\
& from control and idiopathic & cells (scRNAseq, qPCR) & & \\
& $\begin{array}{l}\text { pulmonary fibrosis (IPF) lung } \\
\text { tissue }\end{array}$ & & & \\
& Bronchial epithelial cells isolated \\
& from posttransplant tissue from & & & \\
& healthy donors and CF patients & & - & \\
\hline
\end{tabular}

Calu-3 human lung adenocarcinoma cell line, NCI-H69 and A549 human lung carcinoma cell line, BEAS$2 B$ human bronchial epithelial cell line from a normal subject, $\mathrm{NCI}-\mathrm{H} 441$ human lung papillary adenocarcinoma cell line, CFBE41o- human cystic fibrosis bronchial epithelial cell line, - not studied, $q P C R$ quantitative polymerase chain reaction, $W B$ Western blot

\begin{tabular}{lllll}
\hline Sample & Tissues/cell types & mRNA & Protein & Ref \\
\hline Tissues & Intestinal epithelium (cholera patients) & Expressed & Expressed (IHC) & {$[42]$} \\
& Gastrointestinal tissues & Expressed & - & {$[43,46]$} \\
Cell lines & Caco-2 & Expressed & - & {$[42]$} \\
& & Undetectable & - & {$[43]$} \\
& & - & Expressed (WB \& IF) & {$[44]$} \\
& & Not expressed (PCR) & Not expressed (WB) & {$[16]$} \\
& & & Expressed (WB) & {$[44]$} \\
\hline
\end{tabular}

Caco-2, HT29 and LS174T human adenocarcinoma colorectal epithelial cell lines, CCD841 normal human colon epithelial cell line, HCT116 human colon epithelial cell line from colorectal carcinoma, HT29 and LS174T human epithelial cell lines from colon adenocarcinoma (- not studied, WB Western blot, IF immunofluorescence, IHC immunohistochemistry)
[18]. Two studies then detected SLC6A14 transcripts in mucosal biopsies from duodenum and rectum, respectively [41, 42]. Finally, Anderson et al. compared the expression of SLC6A14 mRNA throughout the gastrointestinal tract and showed that stomach, duodenum, and descending colon expressed high levels of SLC6A14 transcripts, while low levels were found in jejunum, ileum, ascending colon, and transverse colon [43]. Conflicting results have been obtained on the expression of SLC6A14 in the human colon epithelial cell line Caco-2, reporting either some or no SLC6A14 transcripts or protein [16, 42-44]. Interestingly, in mice, SLC6A14 mRNA expression is negligible in the ileum of control animals, but is strongly induced in epithelial ileal cells of CF mice [45].

In vitro, it has been showed that SLC6A14 expression may be modulated by several factors including toxins, bacterial constituents, and proinflammatory cytokines. Indeed,
Flach et al. showed that SLC6A14 mRNA levels are significantly increased after $18 \mathrm{~h}$ of stimulation with cholera toxin in Caco-2 cells [42]. Other molecules have also been shown to regulate SLC6A14 expression. For example, in porcine intestinal cells, Wang et al. showed that SLC6A14 mRNA was increased by L-tryptophan [47]. Ikpa et al. also showed that antibiotic treatment of CF mice induces an important reduction of SLC6A14 transcripts in ileal epithelial cells [45].

\section{Genetic association studies in CF}

Given the diversity of phenotypic severity in CF patients with the same causal $C F T R$ variants, several genetic studies have been conducted to identify CF modifier genes. Among the identified loci, one locus on chromosome $\mathrm{X}$, near the 
Table 4 Genetic associations tested between SLC6A14 variants and digestive and pulmonary manifestations in CF patients

\begin{tabular}{|c|c|c|c|c|c|c|}
\hline rs ID (Alleles) & MAF & Variant localization & Association with & $\begin{array}{l}\text { Number of } \\
\text { CF patients }\end{array}$ & Cohort/patients characteristics & Ref \\
\hline rs7879546 (T/C $)$ & 0.41 & Intergenic & Lung disease severity & \multirow[t]{3}{*}{6365} & \multirow{3}{*}{$\begin{array}{l}\text { Mean age: } 19.5 \text { years; PI (99.8\%); F508del homozy- } \\
\text { gotes }(65 \%)\end{array}$} & \multirow[t]{3}{*}{ [8] } \\
\hline rs5905376 (C/ $\underline{\mathrm{A}})$ & 0.23 & Intergenic & Lung disease severity & & & \\
\hline rs5952223 (C/T) & 0.23 & Intergenic & Lung disease severity & & & \\
\hline \multirow[t]{5}{*}{ rs12839137 (G/A $)$} & \multirow[t]{5}{*}{0.12} & \multirow[t]{5}{*}{ Intergenic } & Presence of meconium ileus & 6135 & $\begin{array}{l}\text { Two independent cohorts (patients with two severe } \\
\text { CFTR mutations): } 3,763 \text { North American (F508del } \\
\text { homozygotes 71.4\%) and 2,372 French ( }>6 \text { years } \\
\text { old) and American patients }\end{array}$ & [14] \\
\hline & & & $\begin{array}{l}\text { No association with pediatric } \\
\text { lung disease severity }\end{array}$ & 815 & $\begin{array}{l}\text { Mean age of lung function measurements: } \\
12.63 \text { years; F508del homozygotes: } 62.3 \%\end{array}$ & \multirow[t]{3}{*}{ [10] } \\
\hline & & & $\begin{array}{l}\text { No association with age of } \\
\text { first infection by } P \text {. aerugi- } \\
\text { nosa }\end{array}$ & 730 & $\begin{array}{l}\text { Median age at first detection of positive } P \text {. aerugi- } \\
\text { nosa culture: } 5.55 \text { years; F508del homozygotes: } \\
61 \%\end{array}$ & \\
\hline & & & $\begin{array}{l}\text { No association with early exo- } \\
\text { crine pancreatic disease }\end{array}$ & 126 & $\begin{array}{l}\text { Median age of the first available IRT measurement: } \\
0.36 \text { years; F508del homozygotes: } 60.3 \%\end{array}$ & \\
\hline & & & $\begin{array}{l}\text { No association with early exo- } \\
\text { crine pancreatic damage }\end{array}$ & 111 & $\begin{array}{l}\text { Patients from Colorado, median age at IRT measure- } \\
\text { ment: } 2 \text { days; F508del homozygotes: } 56 \%\end{array}$ & [11] \\
\hline \multirow[t]{5}{*}{ rs5905283 (슬) } & \multirow[t]{5}{*}{0.47} & \multirow[t]{5}{*}{$\begin{array}{l}\text { Intergenic (2 KB } \\
\text { Upstream Variant) }\end{array}$} & Presence of meconium ileus & 6,135 & $\begin{array}{l}\text { Two independent cohorts (patients with two severe } \\
\text { CFTR mutations): 3,763 North American (F508del } \\
\text { homozygotes 71.4\%) and 2,372 French ( }>6 \text { years } \\
\text { old) and American patients }\end{array}$ & [14] \\
\hline & & & Pediatric lung disease severity & 815 & $\begin{array}{l}\text { Mean age of lung function measurements: } \\
12.63 \text { years; F508del homozygotes: } 62.3 \%\end{array}$ & \multirow[t]{3}{*}{ [10] } \\
\hline & & & $\begin{array}{l}\text { No association with age of } \\
\text { first infection by } P \text {. aerugi- } \\
\text { nosa }\end{array}$ & 730 & $\begin{array}{l}\text { Median age at first detection of positive } P \text {. aerugi- } \\
\text { nosa culture: } 5.55 \text { years; F508del homozygotes: } \\
61 \%\end{array}$ & \\
\hline & & & $\begin{array}{l}\text { No association with early exo- } \\
\text { crine pancreatic phenotypes }\end{array}$ & 126 & $\begin{array}{l}\text { Median age of the first available IRT measurement: } \\
0.36 \text { years; F508del homozygotes: } 60.3 \%\end{array}$ & \\
\hline & & & $\begin{array}{l}\text { No association with early exo- } \\
\text { crine pancreatic damage }\end{array}$ & 111 & $\begin{array}{l}\text { Patients from Colorado, median age at IRT measure- } \\
\text { ment: } 2 \text { days; F508del homozygotes: } 56 \%\end{array}$ & [11] \\
\hline \multirow[t]{8}{*}{ 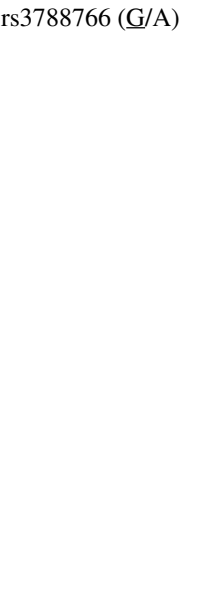 } & \multirow[t]{8}{*}{0.36} & \multirow[t]{8}{*}{ Regulatory region } & Presence of meconium ileus & 6,135 & $\begin{array}{l}\text { Two independent cohorts (patients with two severe } \\
\text { CFTR mutations): } 3,763 \text { North American (F508del } \\
\text { homozygotes 71.4\%) and 2,372 French (>6 years } \\
\text { old) and American patients }\end{array}$ & [14] \\
\hline & & & Pediatric lung disease severity & 815 & $\begin{array}{l}\text { Mean age of lung function measurements: } \\
12.63 \text { years; F508del homozygotes: } 62.3 \%\end{array}$ & \multirow[t]{3}{*}{ [10] } \\
\hline & & & $\begin{array}{l}\text { Age of first infection by } P \text {. } \\
\text { aeruginosa }\end{array}$ & 730 & $\begin{array}{l}\text { Median age at first detection of positive } P \text {. aerugi- } \\
\text { nosa culture: } 5.55 \text { years; F508del homozygotes: } \\
61 \%\end{array}$ & \\
\hline & & & $\begin{array}{l}\text { No association with early exo- } \\
\text { crine pancreatic phenotypes }\end{array}$ & 126 & $\begin{array}{l}\text { Median age of the first available IRT measurement: } \\
0.36 \text { years; F508del homozygotes: } 60.3 \%\end{array}$ & \\
\hline & & & $\begin{array}{l}\text { No association with early exo- } \\
\text { crine pancreatic damage }\end{array}$ & 111 & $\begin{array}{l}\text { Patients from Colorado, median age at IRT measure- } \\
\text { ment: } 2 \text { days; F508del homozygotes: } 56 \%\end{array}$ & [11] \\
\hline & & & Early pulmonary symptoms & 79 & \multirow[t]{2}{*}{ Brazilian patients } & \multirow[t]{2}{*}{ [12] } \\
\hline & & & P. aeruginosa infection & 83 & & \\
\hline & & & Presence of meconium ileus & 6,770 & $\begin{array}{l}\text { Patients with two severe } C F T R \text { mutations associated } \\
\text { with PI; F508del homozygotes: } 64.2 \%\end{array}$ & [9] \\
\hline rs12710568 (G/C) & 0.31 & Regulatory region & Presence of meconium ileus & \multirow[t]{2}{*}{6,770} & \multirow{2}{*}{$\begin{array}{l}\text { Patients with two severe } C F T R \text { mutations associated } \\
\text { with PI; F508del homozygotes: } 64.2 \%\end{array}$} & \multirow[t]{2}{*}{ [9] } \\
\hline rs5905177 ( $\underline{\mathrm{C} / \mathrm{T})}$ & 0.35 & SLC6A14 intron & Presence of meconium ileus & & & \\
\hline
\end{tabular}

Chromosomic position (forward strand); minor allele in the European population, Minor allele Frequency (MAF), data were collected from Ensembl, 1000 Genomes, European population. IRT immunoreactive trypsinogen, PI pancreatic insufficiency

SLC6A14 gene, was associated with a variability in the severity of $\mathrm{CF}$ clinical manifestations including lung disease severity/pulmonary infections or presence of MI/onset of digestive symptoms (Table 4). Linkage disequilibrium pattern of the different genetic variants studies in this review is shown in Fig. 1.
The initial evidence showing that SLC6A14 may be a modifier gene in CF has been described by Sun et al. in a "genome wide association study" (GWAS) involving 6135 CF patients [14]. This study identified a significant association between susceptibility to MI and three SLC6A14 genetic variants (rs12839137, rs5905283, and rs3788766). 


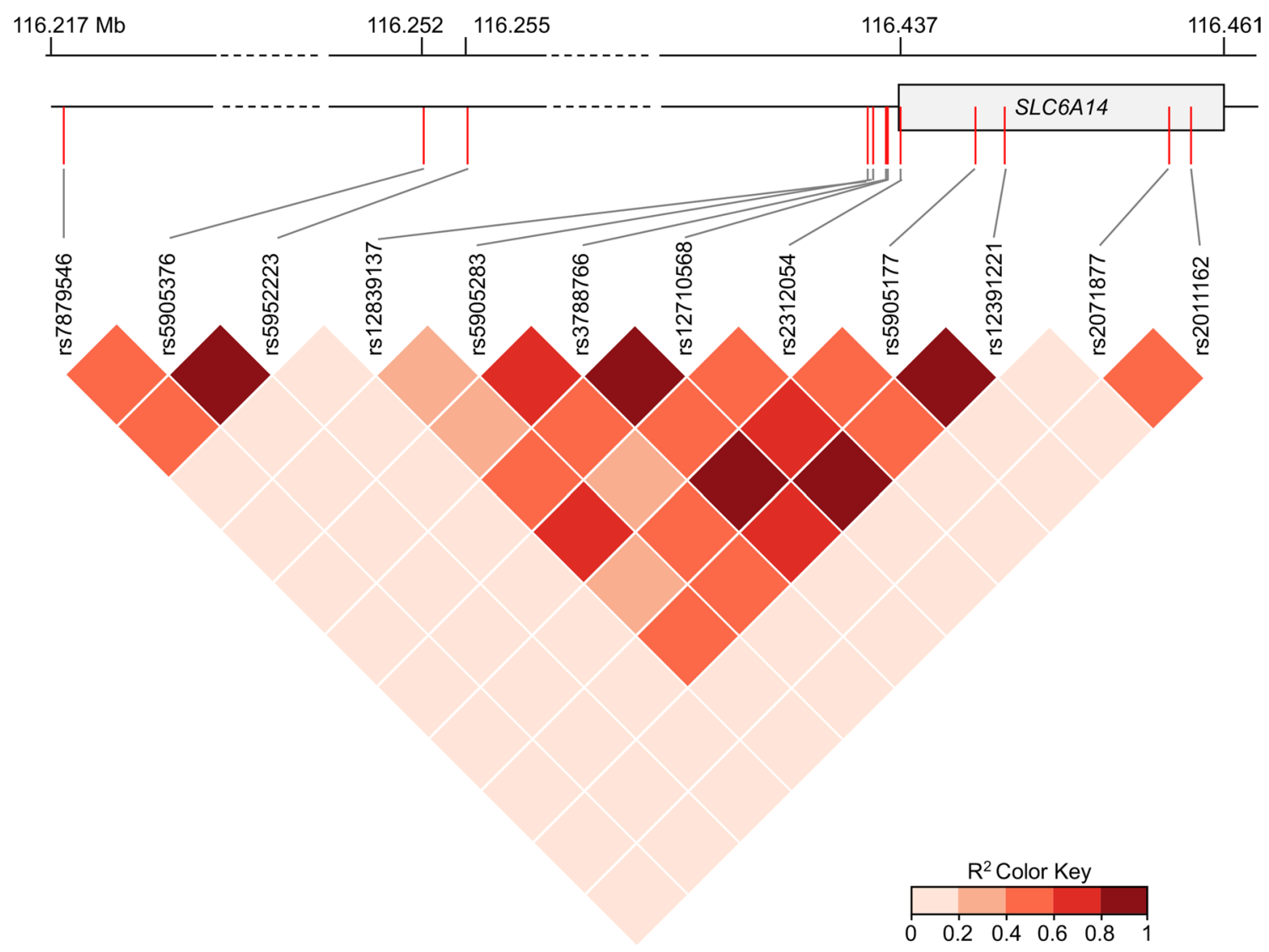

Fig. 1 Linkage disequilibrium (LD) pattern of the twelve SLC6A14 genetic variants studied. The dark red squares indicate pairs in strong LD. $R^{2}$ are from https://ldlink.nci.nih.gov

In a study involving more than $6700 \mathrm{CF}$ patients from the International CF Gene Modifier Consortium, Gong et al. recently replicated the association between susceptibility to MI and rs3788766 [9]. This study also identified an association between MI susceptibility and two new variants (rs12710568 and rs5905177) located within the SLC6A14 regulatory region and SLC6A14 intron, respectively. Several groups performed sex-specific association analysis based on the fact that SLC6A14 gene is located within the region associated with random $\mathrm{X}$-inactivation $[9,14]$. Interestingly, they found higher odd ratios in male than in female only for genetic variants associated with susceptibility to MI.

$\mathrm{Li}$ et al. further assessed the association of MI risk alleles of SLC6A14 with other CF co-morbidities, such as the lung disease severity and age at first $P$. aeruginosa infection [10]. Their study involved 815 CF Canadian pediatric patients who were genotyped for the following SLC6A14 variants: rs12839137, rs5905283, and rs3788766. Among the variants studied, rs5905283 and rs3788766 risk alleles were associated with pediatric lung disease severity; whilst rs 3788766 variant was associated with age at first $P$. aeruginosa infection, as confirmed later in a smaller cohort [12]. In 2015, a GWAS involving 6,365 patients confirmed that SLC6A14 modifies the severity of the lung disease in CF [8]. Indeed, the authors found a significant association between genotypes of three SLC6A14 intergenic variants (rs7879546, rs5905376, and rs5952223) and the lung disease severity.

Gong et al. recently integrated GWAS and tissue-specific gene expression data to determine whether modifier loci on chromosome X (encompassing SLC6A14) influence SLC6A14 mRNA expression levels in different tissues [9]. This kind of analysis indicates whether eQTL (expression quantitative trait loci) colocalize with loci associated with CF phenotypes that may indicate the existence of a genetic regulator. Their results showed that SLC6A14 mRNA expression in CF nasal epithelia and in the pancreas colocalize with the lung disease and MI-associated variants, respectively, suggesting that each locus impacts SLC6A14 expression with tissue specificity. Besides, neither association between SLC6A14 genetic variants and early exocrine pancreatic phenotype nor immunoreactive trypsin levels at birth have been found [10,11]. 


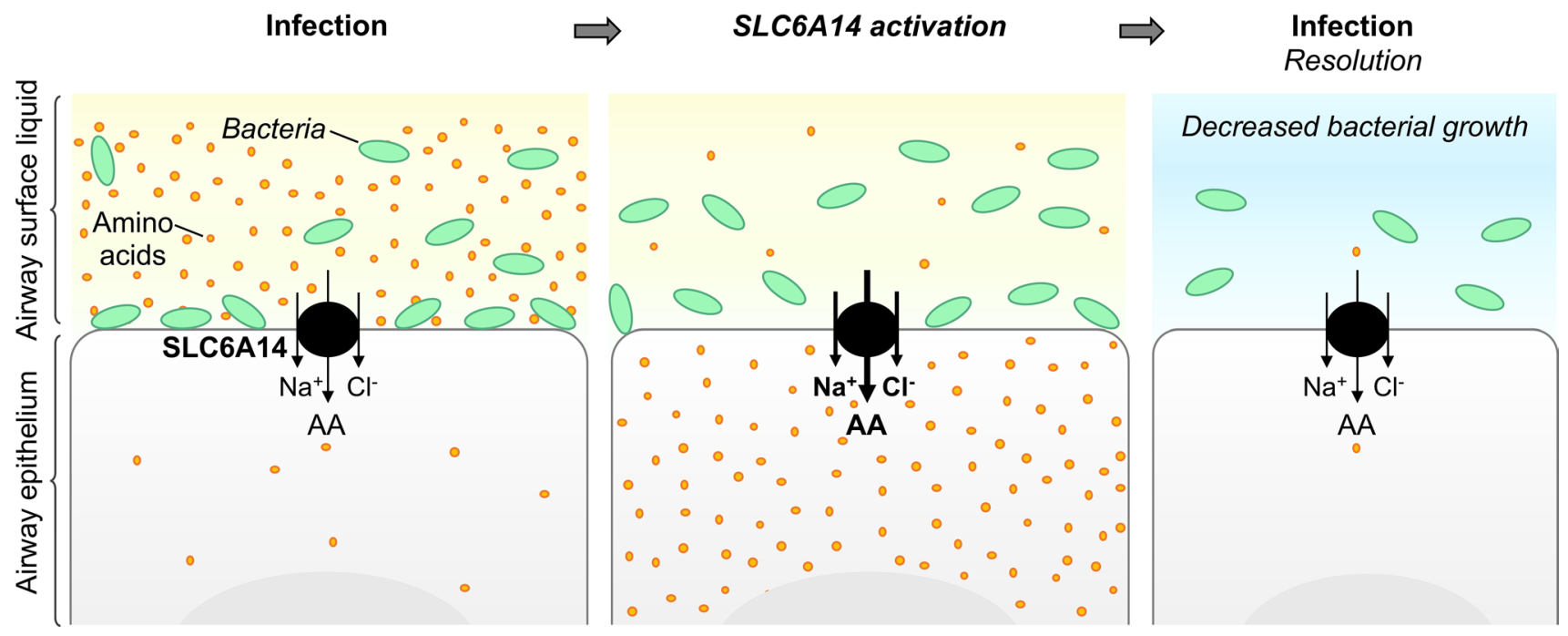

Fig. 2 Proposed mechanism of the role of SLC6A14 in the host response against $P$. aeruginosa. $A A$ amino acids, $\mathrm{Na}^{+}$sodium ions, $\mathrm{Cl}^{-}$chloride ions

\section{Putative biological roles of SLC6A14 in CF}

Several studies showed that SLC6A14 plays a primary role as an amino acid transporter in various epithelial cells and models [32, 48-52]. Taken together, SLC6A14 expression data in human and genetic studies suggest that SLC6A14 may have an important role in the lung and intestinal pathophysiology of CF patients (see Parts 1 and 2).

\section{SLC6A14 function in the lung}

In the lung, it was first suggested that the apical transport of amino acid in the airway epithelial cells may play an important role in infection resolution [32] as pathogens need amino acids to proliferate into the airways. The authors suggested that amino acid transporter at the apical membrane may be activated following infection to rapidly decrease the amino acid concentration of the airway surface liquid (ASL) (Fig. 2). This phenomenon could then help to fight against infections. This hypothesis is supported by the unique characteristics of SLC6A14 allowing it to strongly concentrate all essential amino acids into the cytoplasm of epithelial cells.

As SLC6A14 genetic variants have been associated with age at first acquisition of $P$. aeruginosa in CF patients, Di Paola et al. sought to determine how SLC6A14 might impact the airways colonization by these bacteria [17]. They suggested that exposure to $P$. aeruginosa increased SLC6A14 mRNA expression, inducing a decrease in amino acid concentration in the ASL that resulted in a decrease in P. aeruginosa attachment to the airway epithelial cells rather than a reduced viability of planktonic $P$. aeruginosa. Indeed, they found that purified flagellin from $P$. aeruginosa enhanced SLC6A14 mRNA expression and SLC6A14-dependent arginine import in Calu-3 cells and in primary airway epithelial cells from non-CF and CF patients. Moreover, they showed that pharmacological inhibition of SLC6A14 increased $P$. aeruginosa attachment in non-CF primary airway epithelial cells and slightly in the bronchial epithelial cell line CFBE410-.

Ahmadi et al. recently reported that arginine transport through SLC6A14 increased F508del-CFTR $\mathrm{Cl}^{-}$efflux in $\mathrm{CF}$ airway epithelial cells stimulated with or without a CFTR corrector, lumacaftor [15]. They also observed that this increase in CFTR function induced an increase in the ASL height and that the potentiation of F508del-CFTR channel function in CF cells induced by SLC6A14 arginine uptake occurred via the nitric oxide (NO) signaling pathway (Fig. 3). Finally, they suggested that SLC6A14 activation may be considered as a complement therapy to CFTR correction and potentiation in $\mathrm{CF}$ patients.

\section{SLC6A14 function in the gastrointestinal tract}

Ahmadi et al. also conducted another study to determine the biological function of SLC6A14 in the murine gastrointestinal tract [16]. They first demonstrated that SLC6A14 is a major apical amino acid transporter in the murine colon. Indeed, Slc6a14(-/y) mice exhibited almost $75 \%$ reduction in apical arginine transport compared to WT mice. In CF mice, they observed that Slc6a14 disruption induced a reduction in weight gain and BMI post-weaning and worsen the intestinal phenotype, i.e., decreased F508del-CFTR-mediated fluid secretion. They also highlighted that SLC6A14 does not seem to affect 
Fig. 3 Relationships between SLC6A14, F508del-CFTR, and nitric oxide signaling pathway. $C F$ cystic fibrosis, $A S L$ airway surface liquid, $A A$ amino acids, $\mathrm{Na}^{+}$sodium ions, $\mathrm{Cl}^{-}$chloride ions, $\mathrm{HCO} 3$ - bicarbonate ions, iNOS inducible NO synthetase, $N O$ nitric oxide

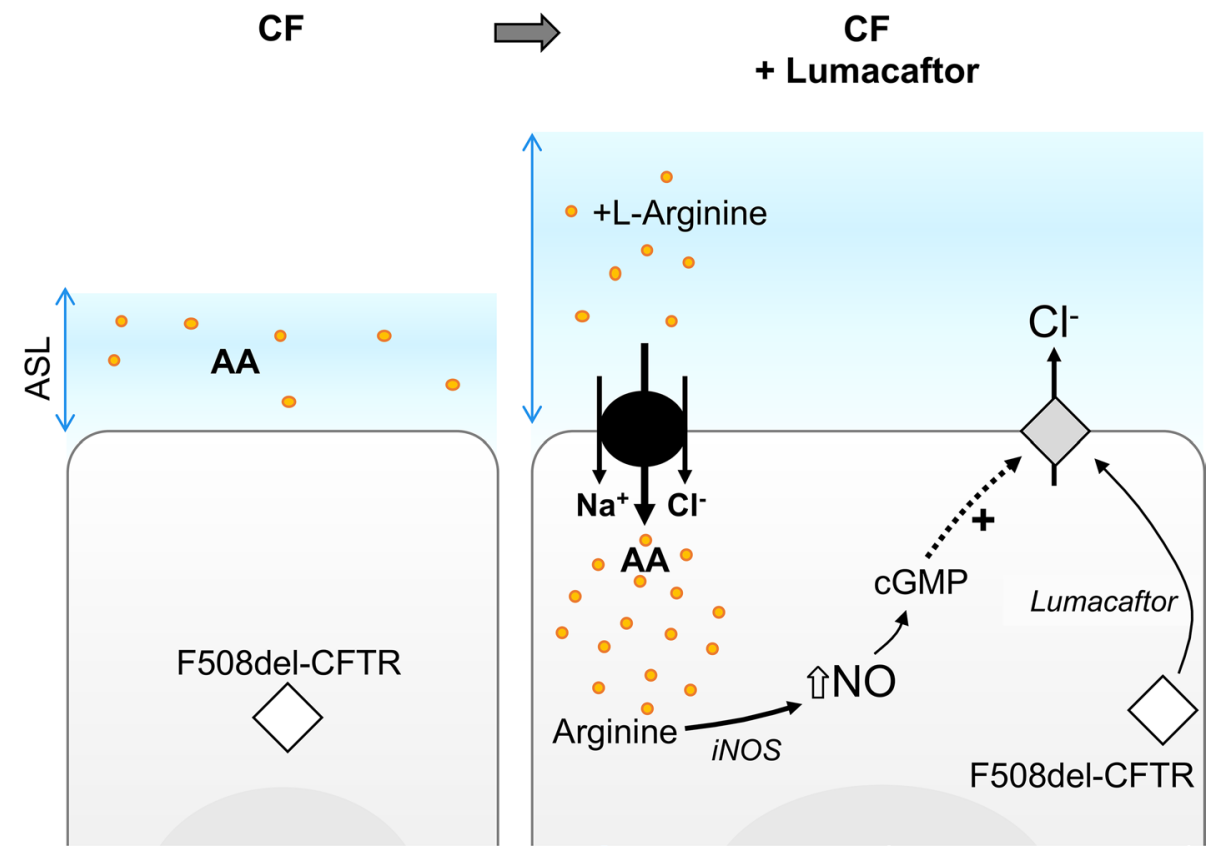

Table 5 Expression of SLC6A14 in other diseases

\begin{tabular}{|c|c|c|c|c|}
\hline Disease & & SLC6A14 expression & Methods & Ref \\
\hline \multirow[t]{4}{*}{ Cancer } & Cervical & Up-regulated & PCR, IF/IH, HIS & [54] \\
\hline & Colorectal & Up-regulated & PCR, Northern blot, IH & {$[55]$} \\
\hline & Pancreatic & Up-regulated & Microarray, qPCR, WB, IF, IH & {$[56,57]$} \\
\hline & Breast $(E R+)$ & Up-regulated & PCR, IF & {$[58]$} \\
\hline \multirow[t]{4}{*}{ Colonic diseases } & Crohn's disease & Up-regulated & qPCR & [46] \\
\hline & Ulcerative colitis & Up-regulated & qPCR, microarray & {$[41,59,60]$} \\
\hline & $\begin{array}{l}\text { Long vs. short duration of ulcerative } \\
\text { colitis }\end{array}$ & Down-regulated & Microarray & {$[61]$} \\
\hline & Ischemic or infectious colitis & Up-regulated & qPCR & {$[60]$} \\
\hline Cholera & Acute vs. convalescence phase & Up-regulated & Microarray, qPCR, IH & [42] \\
\hline \multirow[t]{2}{*}{ IPF } & IPF & Down-regulated & scRNAseq & [36] \\
\hline & IPF vs. NSIP & Up-regulated & Microarray & {$[62]$} \\
\hline
\end{tabular}

$E R+$ estrogen receptor-positive, $I P F$ idiopathic pulmonary fibrosis, NSIP non-specific interstitial pneumonia. If not specifically mentioned, the expression of SLC6A14 is relative to control patients. IF immunofluorescence, IH immunohistochemistry, HIS hybridization in situ, $P C R$ polymerase chain reaction, $W B$ western blot

the processing or stability of F508del-CFTR neither coimmunoprecipitated with F508del-CFTR in an F508delCFTR BHK over-expression system, which led them to investigate intracellular signaling such as NO synthesis. They observed that SLC6A14 inhibition impaired arginine uptake by intestinal epithelial cells inducing both a decrease in NO production and cGMP regulation of F508del-CFTR. These results suggest that an increase in SLC6A14 activity may enhance NO production and F508del-CFTR residual activity in CF tissues. However, it is not known whether these mechanisms are conserved in humans.

It has to be emphasized that in the lung or the intestine, functional studies were conducted with either overexpression (plasmid) or inhibition experiments (siRNA) of the whole gene. The role of the specific genetic variants identified in genetic studies (see Part entitled "Genetic association studies in $\mathrm{CF}^{\prime}$ ) is not yet known and further elucidation is warranted. 
Table 6 Genetic associations tested between SLC6A14 variants and diseases

\begin{tabular}{|c|c|c|c|c|c|}
\hline rs ID (alleles) & MAF & Variant localization & Association with & Number of patients/cohort characteristics & $\operatorname{Ref}$ \\
\hline rs2312054 (A/T) & 0.21 & SLC6A14 intron & Food intake & 344 children, age $7-8$ years & [70] \\
\hline rs12391221 ( $\underline{\mathrm{C} / \mathrm{A}})$ & 0.30 & SLC6A14 intron & Food intake & 344 children, age $7-8$ years & [70] \\
\hline \multirow[t]{2}{*}{ rs2071877 (C/T) } & 0.30 & SLC6A14 intron & Obesity & 1267 obese adults and 649 lean controls (French) & [71] \\
\hline & & & Adiposity & 344 children, age $7-8$ years & [70] \\
\hline \multirow[t]{4}{*}{ rs2011162 ( $\underline{\mathrm{C} / \mathrm{G})}$} & 0.45 & SLC6A14 exon $14 ; 3^{\prime} \mathrm{UTR}$ & Obesity & $\begin{array}{l}\text { Two independent cohorts: } 117 \text { obese and } 182 \text { controls } \\
\text { (Finnish); } 837 \text { obese and } 968 \text { controls (Finnish and } \\
\text { Swedish) }\end{array}$ & [72] \\
\hline & & & Obesity & 1267 obese adults and 649 lean controls (French) & [71] \\
\hline & & & $\begin{array}{l}\text { Reduced fat } \\
\text { oxidation in } \\
\text { women }\end{array}$ & $\begin{array}{l}722 \text { obese subjects of white European origin ( } 541 \text { women, } \\
181 \text { men), age } 20-25 \text { years }\end{array}$ & [73] \\
\hline & & & Male infertility & $\begin{array}{l}370 \text { infertile men and } 241 \text { fertile controls (Macedonian } \\
\text { and Slovenian) }\end{array}$ & [74] \\
\hline $\begin{array}{l}\text { rs2312054(A)/ } \\
\text { rs2071877(C)/ } \\
\text { rs2011162(G) haplotype }\end{array}$ & & & Male infertility & $\begin{array}{l}370 \text { infertile men and } 241 \text { fertile controls (Macedonian } \\
\text { and Slovenian) }\end{array}$ & {$[74]$} \\
\hline
\end{tabular}

Chromosomic position (forward strand); Alleles (Minor), Minor allele Frequency (MAF), data were collected from Ensembl, 1000 Genomes, European population

\section{SLC6A14 in non-CF diseases}

\section{SLC6A14 expression in other diseases}

SLC6A14 expression has been shown to be differentially up-regulated in several pathological contexts (Table 5), especially in cancer and colonic diseases (reviewed in [53]).

\section{Cancer}

SLC6A14 is significantly upregulated in tissues from cervical [54], colorectal [55], pancreatic [56, 57], and estrogen receptor-positive $(\mathrm{ER}+)$ breast cancer [58]. In ER+ breast cancer, high expression of SLC6A14 mRNA has been correlated with a better survival among patients [63]. Using a mouse model of spontaneous breast cancer, Babu et al. showed that its development and progression was significantly decreased when the mice were crossed with Slc6al4 $4^{-/}$mice [64]. The molecular mechanisms associated with these up- or down-regulations are largely unknown. SLC6A14 expression was shown to be regulated by estrogen [58] which explains its specific increased expression in $\mathrm{ER}+$ but not in ER- breast cancer. Also, inverse expression patterns of SLC6A14 mRNA and the microRNA (miR)-23a $[65,66]$ were found suggesting its regulatory effect. However, no functional studies (using miR mimic or inhibitors) confirmed miR-23a involvement in SLC6A14 expression regulation. In contrast, inverse correlation of miR-23b-3p [67] and SLC6A14 expression was recently confirmed. Functional studies have shown that the downregulation of SLC6A14 observed in endocrine therapy (ER + breast cancer standard of care)-resistant cells is associated with an increase of miR23b-3p [63].

\section{Colonic diseases}

SLC6A14 mRNA levels are significantly higher in colonic mucosal specimens obtained from patients with Crohn's disease compared to controls [46]. SLC6A14 expression was also increased in rectal and colonic biopsies from patients with ulcerative colitis or infectious/ischemic colitis compared to controls, suggesting that SLC6A14 upregulation might be the result of the inflammatory context rather than a specific pathophysiological consequence of the ulcerative colitis [41, 59, 60, 68]. Low et al. further observed that SLC6A14 was down-regulated in colonic biopsies from patients with long-duration of ulcerative colitis compared with patients with short duration [61]. In rats, D'Argenio et al. showed that experimental colitis induced a marked decrease in SLC6A14 transcript expression in the colon [69]. Finally, Kou et al. found that colon cancer cell lines overexpressed SLC6A14 compared to normal colon cells [44].

\section{Idiopathic pulmonary fibrosis}

SLC6A14 has been found to be downregulated in alveolartype II cells of idiopathic pulmonary fibrosis (IPF) patients [36], while it is overexpressed in specimens from explanted lungs of patients with non-specific interstitial pneumonia compared to specimens from IPF patients [62]. 


\section{Infectious diseases}

SLC6A14 mRNA levels have been shown to be increased in biopsies of duodenum collected during the acute phase of cholera compared to biopsies collected during convalescence phase [42].

\section{Genetic associations studies in other diseases}

Four additional SLC6A14 genetic variants have been associated with phenotypic variability in other diseases than $\mathrm{CF}$ (Table 6).

SLC6A14 genetic variants have been associated with obesity in different populations (Table 6). In a candidate gene analysis, later replicated in an independent cohort, Suviolahti et al. found significant differences in SLC6A14 rs2011162 genetic variant allele frequencies between obese and nonobese subjects [72]. Another study suggested an association between the rs2011162 and fat oxidation in women which may be, when not adapted to fat intake, responsible to weight gain over time [73]. Finally, in a French family cohort study comprising of 1,267 obese adults and 649 lean control subjects, Durand et al. found a significant association between rs2011162 genetic variant and obesity. They observed that the risk allele was associated with higher body fat and modified perception of hunger and satiety in adult women with moderate obesity and in obese girls [71]. Durand et al. also identified an association between SLC6A14 rs2071877 genetic variant and obesity in a French cohort [71]. This variant has also been associated with sum of triceps and subscapular skinfolds thickness, an objective measure of adiposity, in boys 7-8 of age [70]. Finally, Miranda et al. also found evidences of associations between two other genetic variants, rs2312054 and rs12391221, and several parameters used to assess the food intake in children [70].

SLC6A14 genetic variants have been also associated with male infertility. Indeed, Noveski et al. found that rs2011162 alone and rs2011162(G)/rs2071877(C)/rs2312054(A) haplotype were differently distributed among fertile and infertile groups in their cohort [74]. As rs2011162 is located within the 3'UTR region of SLC6A14, they investigated the possible consequences of this genetic variation on the RNA secondary structure. They found a significant structural effect of this genetic variant that may result in a differential mRNA expression depending on the allele.

It was recently shown that SLC6A14 expression quantitative trait loci (eQTL) from nasal epithelial cells and pancreas tissues coincide with lung disease and meconium ileus-associated variants, respectively, supporting an important role for SLC6A14 variants in CF [9]. However, whether in CF or other diseases, the functional in vitro/in vivo consequences of identified SLC6A14 genetic variants on SLC6A14 protein expression and/or function have never been studied. This gap in knowledge needs to be addressed to better understand the molecular mechanisms by which SLC6A14 affect phenotypes or diseases. SLC6A14 genetic variants described in this review are located in the non-coding region either intergenic or located in the regulatory region (promoter), introns, or in the 3'UTR region of SLC6A14, and, subsequently, do not modify the amino acid sequence of SLC6A14 protein. However, these variants may have multiple effects not only on SLC6A14, but also on nearby and/or distant genes. For example, genetic variants located in the promoter may affect transcriptional activity by altering transcription factor binding. Other functional consequences of these SNPs have to be studied including DNA methylation and histone modifications, alternative splicing, conformation and stability of mRNA as well as structure, expression level, and function of proteins. Even if bioinformatic tools may predict functional consequences of genetic variants, downstream in vitro/ in vivo experimental studies will also be necessary. Successfully used for several complex traits, genome-editing technologies may also be used to create isogenic cell lines with specific alleles to assess their functionality including chromatin structure, transcription factor binding, gene and protein expression, and specific cellular assays [75]. Furthermore, as previously mentioned, in addition to the impact of genetic variants, SLC6A14 expression can be regulated by environmental factors (inflammatory molecules, pathogens, and pharmacological treatments) and possibly age (fetal vs. adult, Table 1). Thus, the development of different experimental models to identify the causality of SLC6A14 expression and function variability over the course of disease progression will be a major challenge.

\section{Conclusion}

SLC6A14 seems to be predominantly expressed in epithelial cells of the human lung and to a lesser extent in the human gastrointestinal epithelium. Importantly, SLC6A14 expression profiles appear to be different between human and mice, suggesting that studies investigating the biological roles of this protein in murine models may not directly correlate with findings obtained in human models. Several groups have observed that SLC6A14 levels are up- or down-regulated in pathological conditions, however, the mechanisms involved in these dysregulations have mostly not been elucidated. Moreover, some studies have demonstrated that inflammatory mediators and pathogen molecules may impact SLC6A14 expression.

Furthermore, genetic studies highlight that SLC6A14 genetic variants modulate the severity of digestive and pulmonary diseases in $\mathrm{CF}$ patients. The biological function of this pleiotropic modifier gene is not fully explained and 
the biological direct consequences of identified variants in genetic studies remained to be clarified. However, some recent studies suggest that SLC6A14 may play an important role in the response to respiratory infection and fluid secretion related to CFTR. Thus, SLC6A14 may be a potential therapeutic target to improve anti-infective response and CFTR function and/or correction in CF patients in a personalized way.

Acknowledgements The Genotype-Tissue Expression (GTEx) Project was supported by the Common Fund of the Office of the Director of the National Institutes of Health, and by NCI, NHGRI, NHLBI, NIDA, NIMH, and NINDS. The data described in this manuscript were obtained from the GTEx Portal on 12/18/2018.

Funding LG received a grant from the French cystic fibrosis non-profit organization Vaincre la mucoviscidose (RF20180502243) and a PHC (Programme Hubert Curien) PHC FASIC 2017. MR received a postdoctoral fellowship from the French cystic fibrosis non-profit organization Vaincre la mucoviscidose (RF20180502243).

Open Access This article is licensed under a Creative Commons Attribution 4.0 International License, which permits use, sharing, adaptation, distribution and reproduction in any medium or format, as long as you give appropriate credit to the original author(s) and the source, provide a link to the Creative Commons licence, and indicate if changes were made. The images or other third party material in this article are included in the article's Creative Commons licence, unless indicated otherwise in a credit line to the material. If material is not included in the article's Creative Commons licence and your intended use is not permitted by statutory regulation or exceeds the permitted use, you will need to obtain permission directly from the copyright holder. To view a copy of this licence, visit http://creativecommons.org/licenses/by/4.0/.

\section{References}

1. Kerem B, Rommens JM, Buchanan JA, Markiewicz D, Cox TK et al (1989) Identification of the cystic fibrosis gene: genetic analysis. Science 245(4922):1073-1080. https://doi.org/10.1126/scien ce. 2570460

2. Riordan JR, Rommens JM, Kerem B, Alon N, Rozmahel R et al (1989) Identification of the cystic fibrosis gene: cloning and characterization of complementary DNA. Science 245(4922):1066-1073

3. Rommens JM, Iannuzzi MC, Kerem B, Drumm ML, Melmer G et al (1989) Identification of the cystic fibrosis gene: chromosome walking and jumping. Science 245(4922):1059-1065. https://doi. org/10.1126/science. 2772657

4. Kerem E, Viviani L, Zolin A, MacNeill S, Hatziagorou E et al (2014) Factors associated with FEV1 decline in cystic fibrosis: analysis of the ECFS patient registry. Eur Respir J 43(1):125-133. https://doi.org/10.1183/09031936.00166412

5. Cutting GR (2015) Cystic fibrosis genetics: from molecular understanding to clinical application. Nat Rev Genet 16(1):45-56. https ://doi.org/10.1038/nrg3849

6. Guillot L, Beucher J, Tabary O, Le Rouzic P, Clement A et al (2014) Lung disease modifier genes in cystic fibrosis. Int $\mathbf{J}$ Biochem Cell Biol 52:83-93. https://doi.org/10.1016/j.bioce 1.2014.02.011

7. McKone EF, Emerson SS, Edwards KL, Aitken ML (2003) Effect of genotype on phenotype and mortality in cystic fibrosis: a retrospective cohort study. Lancet 361(9370):1671-1676. https ://doi.org/10.1016/S0140-6736(03)13368-5

8. Corvol H, Blackman SM, Boelle PY, Gallins PJ, Pace RG et al (2015) Genome-wide association meta-analysis identifies five modifier loci of lung disease severity in cystic fibrosis. Nat Commun 6:8382. https://doi.org/10.1038/ncomms9382

9. Gong J, Wang F, Xiao B, Panjwani N, Lin F et al (2019) Genetic association and transcriptome integration identify contributing genes and tissues at cystic fibrosis modifier loci. PLoS Genet 15(2):e1008007. https://doi.org/10.1371/journal.pgen.1008007

10. Li W, Soave D, Miller MR, Keenan K, Lin F et al (2014) Unraveling the complex genetic model for cystic fibrosis: pleiotropic effects of modifier genes on early cystic fibrosis-related morbidities. Hum Genet 133(2):151-161. https://doi.org/10.1007/s0043 9-013-1363-7

11. Miller MR, Soave D, Li W, Gong J, Pace RG et al (2015) Variants in solute carrier SLC26A9 modify prenatal exocrine pancreatic damage in cystic fibrosis. J Pediatr 166(5):1152-1157. https://doi. org/10.1016/j.jpeds.2015.01.044(e1156)

12. Pereira SV, Ribeiro JD, Bertuzzo CS, Marson FAL (2017) Association of clinical severity of cystic fibrosis with variants in the SLC gene family (SLC6A14, SLC26A9, SLC11A1 and SLC9A3). Gene 629:117-126. https://doi.org/10.1016/j.gene.2017.07.068

13. Pereira SVN, Ribeiro JD, Bertuzzo CS, Marson FAL (2018) Interaction among variants in the SLC gene family (SLC6A14, SLC26A9, SLC11A1, and SLC9A3) and CFTR mutations with clinical markers of cystic fibrosis. Pediatr Pulmonol 53(7):888 900. https://doi.org/10.1002/ppul.24005

14. Sun L, Rommens JM, Corvol H, Li W, Li X et al (2012) Multiple apical plasma membrane constituents are associated with susceptibility to meconium ileus in individuals with cystic fibrosis. Nat Genet 44(5):562-569. https://doi.org/10.1038/ng.2221

15. Ahmadi S, Wu YS, Li M, Ip W, Lloyd-Kuzik A et al (2019) Augmentation of CFTR function in human bronchial epithelial cells via SLC6A14-dependent amino acid uptake: implications for treatment of cystic fibrosis. Am J Respir Cell Mol Biol. https:// doi.org/10.1165/rcmb.2019-0094OC

16. Ahmadi S, Xia S, Wu YS, DiPaola M, Kissoon R et al (2018) SLC6A14, an amino acid transporter, modifies the primary CF defect in fluid secretion. Elife. https://doi.org/10.7554/eLife.37963

17. DiPaola M, Park AJ, Ahmadi S, Roach EJ, Wu YS et al (2017) SLC6A14 is a genetic modifier of cystic fibrosis that regulates pseudomonas aeruginosa attachment to human bronchial epithelial cells. MBio. https://doi.org/10.1128/mBio.02073-17

18. Sloan JL, Mager S (1999) Cloning and functional expression of a human $\mathrm{Na}(+)$ and $\mathrm{Cl}(-)$-dependent neutral and cationic amino acid transporter B(0+). J Biol Chem 274(34):23740-23745. https ://doi.org/10.1074/jbc.274.34.23740

19. Pramod AB, Foster J, Carvelli L, Henry LK (2013) SLC6 transporters: structure, function, regulation, disease association and therapeutics. Mol Aspects Med 34(2-3):197-219. https://doi. org/10.1016/j.mam.2012.07.002

20. Rogala-Koziarska K, Samluk L (1866) Nalecz KA (2019) Amino acid transporter SLC6A14 depends on heat shock protein HSP90 in trafficking to the cell surface. Biochim Biophys Acta Mol Cell Res 10:1544-1555. https://doi.org/10.1016/j.bbamcr.2019.07.009

21. Kovalchuk V, Samluk L, Juraszek B, Jurkiewicz-Trzaska D, Sucic $S$ et al (1866) (2019) Trafficking of the amino acid transporter $\mathrm{B}(0,+)($ SLC6A14) to the plasma membrane involves an exclusive interaction with SEC24C for its exit from the endoplasmic reticulum. Biochim Biophys Acta Mol Cell Res 2:252-263. https ://doi.org/10.1016/j.bbamcr.2018.11.005

22. Roadmap Epigenomics C, Kundaje A, Meuleman W, Ernst J, Bilenky $M$ et al (2015) Integrative analysis of 111 reference human epigenomes. Nature 518(7539):317-330. https://doi. org/10.1038/nature14248 
23. Lin S, Lin Y, Nery JR, Urich MA, Breschi A et al (2014) Comparison of the transcriptional landscapes between human and mouse tissues. Proc Natl Acad Sci USA 111(48):17224-17229. https:// doi.org/10.1073/pnas.1413624111

24. Asmann YW, Necela BM, Kalari KR, Hossain A, Baker TR et al (2012) Detection of redundant fusion transcripts as biomarkers or disease-specific therapeutic targets in breast cancer. Cancer Res 72(8):1921-1928. https://doi.org/10.1158/0008-5472. CAN-11-3142

25. Barbosa-Morais NL, Irimia M, Pan Q, Xiong HY, Gueroussov $S$ et al (2012) The evolutionary landscape of alternative splicing in vertebrate species. Science 338(6114):1587-1593. https://doi. org/10.1126/science. 1230612

26. Derrien T, Johnson R, Bussotti G, Tanzer A, Djebali S et al (2012) The GENCODE v7 catalog of human long noncoding RNAs: analysis of their gene structure, evolution, and expression. Genome Res 22(9):1775-1789. https://doi.org/10.1101/gr.13215 9.111

27. Consortium GT (2015) Human genomics. The genotype-tissue expression (GTEx) pilot analysis: multitissue gene regulation in humans. Science 348(6235):648-660. https://doi.org/10.1126/ science. 1262110

28. Keane TM, Goodstadt L, Danecek P, White MA, Wong K et al (2011) Mouse genomic variation and its effect on phenotypes and gene regulation. Nature 477(7364):289-294. https://doi. org/10.1038/nature 10413

29. Brawand D, Soumillon M, Necsulea A, Julien P, Csardi G et al (2011) The evolution of gene expression levels in mammalian organs. Nature 478(7369):343-348. https://doi.org/10.1038/natur e10532

30. Huntley MA, Lou M, Goldstein LD, Lawrence M, Dijkgraaf GJ et al (2016) Complex regulation of ADAR-mediated RNA-editing across tissues. BMC Genomics 17:61. https://doi.org/10.1186/ s12864-015-2291-9

31. Soumillon M, Necsulea A, Weier M, Brawand D, Zhang X et al (2013) Cellular source and mechanisms of high transcriptome complexity in the mammalian testis. Cell Rep 3(6):2179-2190. https://doi.org/10.1016/j.celrep.2013.05.031

32. Galietta LJ, Musante L, Romio L, Caruso U, Fantasia A et al (1998) An electrogenic amino acid transporter in the apical membrane of cultured human bronchial epithelial cells. Am J Physiol 275(5):L917-923. https://doi.org/10.1152/ajplu ng.1998.275.5.L917

33. Sloan JL, Grubb BR, Mager S (2003) Expression of the amino acid transporter ATB 0+ in lung: possible role in luminal protein removal. Am J Physiol Lung Cell Mol Physiol 284(1):L39-49. https://doi.org/10.1152/ajplung.00164.2002

34. Ingoglia F, Visigalli R, Rotoli BM, Barilli A, Riccardi B et al (1858) (2016) Functional activity of L-carnitine transporters in human airway epithelial cells. Biochim Biophys Acta 2:210-219. https://doi.org/10.1016/j.bbamem.2015.11.013

35. Luo Q, Yang B, Tao W, Li J, Kou L et al (2017) ATB $(0,+)$ transporter-mediated targeting delivery to human lung cancer cells via aspartate-modified docetaxel-loading stealth liposomes. Biomater Sci 5(2):295-304. https://doi.org/10.1039/c6bm00788k

36. Xu Y, Mizuno T, Sridharan A, Du Y, Guo M et al (2016) Singlecell RNA sequencing identifies diverse roles of epithelial cells in idiopathic pulmonary fibrosis. JCI Insight 1(20):e90558. https:// doi.org/10.1172/jci.insight. 90558

37. Rotoli BM, Bussolati O, Sala R, Gazzola GC, Dall'Asta V (2005) The transport of cationic amino acids in human airway cells: expression of system $\mathrm{y}+\mathrm{L}$ activity and transepithelial delivery of NOS inhibitors. FASEB J 19(7):810-812. https://doi.org/10.1096/ fj.04-2924fje

38. Muller A, Chiotellis A, Keller C, Ametamey SM, Schibli R et al (2014) Imaging tumour ATB0,+ transport activity by PET with the cationic amino acid O-2((2-[18F]fluoroethyl)methyl-amino) ethyltyrosine. Mol Imaging Biol 16(3):412-420. https://doi. org/10.1007/s11307-013-0711-2

39. Gorrieri G, Scudieri P, Caci E, Schiavon M, Tomati V et al (2016) Goblet cell hyperplasia requires high bicarbonate transport to support mucin release. Sci Rep 6:36016. https://doi.org/10.1038/ srep36016

40. Chin S, Hung M, Won A, Wu YS, Ahmadi S et al (2018) Lipophilicity of the cystic fibrosis drug, Ivacaftor (VX-770), and its destabilizing effect on the major CF-causing mutation: F508del. Mol Pharmacol 94(2):917-925. https://doi.org/10.1124/mol.118.11217 7

41. Eriksson A, Flach CF, Lindgren A, Kvifors E, Lange S (2008) Five mucosal transcripts of interest in ulcerative colitis identified by quantitative real-time PCR: a prospective study. BMC Gastroenterol 8:34. https://doi.org/10.1186/1471-230X-8-34

42. Flach CF, Qadri F, Bhuiyan TR, Alam NH, Jennische E et al (2007) Differential expression of intestinal membrane transporters in cholera patients. FEBS Lett 581(17):3183-3188. https://doi. org/10.1016/j.febslet.2007.06.001

43. Anderson CM, Howard A, Walters JR, Ganapathy V, Thwaites DT (2009) Taurine uptake across the human intestinal brush-border membrane is via two transporters: H+-coupled PAT1 (SLC36A1) and $\mathrm{Na}+-$ and $\mathrm{Cl}(-)$-dependent TauT (SLC6A6). J Physiol 587(Pt 4):731-744. https://doi.org/10.1113/jphysiol.2008.164228

44. Kou L, Yao Q, Sivaprakasam S, Luo Q, Sun Y et al (2017) Dual targeting of 1-carnitine-conjugated nanoparticles to OCTN2 and $\operatorname{ATB}(0,+)$ to deliver chemotherapeutic agents for colon cancer therapy. Drug Deliv 24(1):1338-1349. https://doi. org/10.1080/10717544.2017.1377316

45. Ikpa PT, Meijsen KF, Nieuwenhuijze NDA, Dulla K, de Jonge HR et al (2019) Transcriptome analysis of the distal small intestine of Cftr null mice. Genomics. https://doi.org/10.1016/j.ygeno .2019.06.028

46. Eriksson A, Jennische E, Flach CF, Jorge A, Lange S (2008) Realtime PCR quantification analysis of five mucosal transcripts in patients with Crohn's disease. Eur J Gastroenterol Hepatol 20(4):290-296. https://doi.org/10.1097/MEG.0b013e3282f3557c

47. Wang H, Ji Y, Wu G, Sun K, Sun Y et al (2015) 1-Tryptophan activates mammalian target of rapamycin and enhances expression of tight junction proteins in intestinal porcine epithelial cells. J Nutr 145(6):1156-1162. https://doi.org/10.3945/jn.114.209817

48. Anderson CM, Ganapathy V, Thwaites DT (2008) Human solute carrier SLC6A14 is the beta-alanine carrier. J Physiol 586(17):4061-4067. https://doi.org/10.1113/jphysiol.2008.15450 0

49. Jain-Vakkalagadda B, Pal D, Gunda S, Nashed Y, Ganapathy V et al (2004) Identification of a Na+-dependent cationic and neutral amino acid transporter, $\mathrm{B}(0,+)$, in human and rabbit cornea. Mol Pharm 1(5):338-346

50. Kekuda R, Torres-Zamorano V, Fei YJ, Prasad PD, Li HW et al (1997) Molecular and functional characterization of intestinal $\mathrm{Na}(+)$-dependent neutral amino acid transporter B0. Am J Physiol 272(6 Pt 1):G1463-1472. https://doi.org/10.1152/ajpgi .1997.272.6.G1463

51. Uchiyama T, Fujita T, Gukasyan HJ, Kim KJ, Borok Z et al (2008) Functional characterization and cloning of amino acid transporter $\mathrm{B}(0,+)(\mathrm{ATB}(0,+))$ in primary cultured rat pneumocytes. J Cell Physiol 214(3):645-654. https://doi.org/10.1002/jcp.21254

52. Ugawa S, Sunouchi Y, Ueda T, Takahashi E, Saishin Y et al (2001) Characterization of a mouse colonic system $\mathrm{B}(0+)$ amino acid transporter related to amino acid absorption in colon. Am J Physiol Gastrointest Liver Physiol 281(2):G365-370. https://doi. org/10.1152/ajpgi.2001.281.2.G365

53. Sikder MOF, Yang S, Ganapathy V, Bhutia YD (2017) The $\mathrm{Na}(+) /$ $\mathrm{Cl}(-)$-coupled, broad-specific, amino acid transporter SLC6A14 
$(\operatorname{ATB}(0,+))$ : emerging roles in multiple diseases and therapeutic potential for treatment and diagnosis. AAPS J 20(1):12. https:// doi.org/10.1208/s12248-017-0164-7

54. Gupta N, Prasad PD, Ghamande S, Moore-Martin P, Herdman AV et al (2006) Up-regulation of the amino acid transporter ATB $(0,+)$ (SLC6A14) in carcinoma of the cervix. Gynecol Oncol 100(1):813. https://doi.org/10.1016/j.ygyno.2005.08.016

55. Gupta N, Miyauchi S, Martindale RG, Herdman AV, Podolsky R et al (2005) Upregulation of the amino acid transporter ATB0,+ (SLC6A14) in colorectal cancer and metastasis in humans. Biochim Biophys Acta 1741(1-2):215-223. https://doi.org/10.1016/j. bbadis.2005.04.002

56. Coothankandaswamy V, Cao S, Xu Y, Prasad PD, Singh PK et al (2016) Amino acid transporter SLC6A14 is a novel and effective drug target for pancreatic cancer. Br J Pharmacol 173(23):32923306. https://doi.org/10.1111/bph.13616

57. Penheiter AR, Erdogan S, Murphy SJ, Hart SN, Felipe Lima J et al (2015) Transcriptomic and immunohistochemical profiling of SLC6A14 in pancreatic ductal adenocarcinoma. Biomed Res Int 2015:593572. https://doi.org/10.1155/2015/593572

58. Karunakaran S, Ramachandran S, Coothankandaswamy V, Elangovan S, Babu E et al (2011) SLC6A14 (ATB0,+) protein, a highly concentrative and broad specific amino acid transporter, is a novel and effective drug target for treatment of estrogen receptor-positive breast cancer. J Biol Chem 286(36):31830-31838. https://doi. org/10.1074/jbc.M111.229518

59. Flach CF, Eriksson A, Jennische E, Lange S, Gunnerek C et al (2006) Detection of elafin as a candidate biomarker for ulcerative colitis by whole-genome microarray screening. Inflamm Bowel Dis 12(9):837-842. https://doi.org/10.1097/01.mib.0000232469 .23574 .11

60. Van der Goten J, Vanhove W, Lemaire K, Van Lommel L, Machiels K et al (2014) Integrated miRNA and mRNA expression profiling in inflamed colon of patients with ulcerative colitis. PLoS ONE 9(12):e116117. https://doi.org/10.1371/journ al.pone. 0116117

61. Low END, Mokhtar NM, Wong Z, Raja Ali RA (2019) Colonic mucosal transcriptomic changes in patients with long-duration ulcerative colitis revealed colitis-associated cancer pathways. J Crohns Colitis 13(6):755-763. https://doi.org/10.1093/ecco-jcc/ jjz002

62. Cecchini MJ, Hosein K, Howlett CJ, Joseph M, Mura M (2018) Comprehensive gene expression profiling identifies distinct and overlapping transcriptional profiles in non-specific interstitial pneumonia and idiopathic pulmonary fibrosis. Respir Res 19(1):153. https://doi.org/10.1186/s12931-018-0857-1

63. Bacci M, Lorito N, Ippolito L, Ramazzotti M, Luti S et al (2019) Reprogramming of amino acid transporters to support aspartate and glutamate dependency sustains endocrine resistance in breast cancer. Cell Rep 28(1):104-118. https://doi.org/10.1016/j.celre p.2019.06.010(e108)

64. Babu E, Bhutia YD, Ramachandran S, Gnanaprakasam JP, Prasad PD et al (2015) Deletion of the amino acid transporter Slc6a14 suppresses tumour growth in spontaneous mouse models of breast cancer. Biochem J 469(1):17-23. https://doi.org/10.1042/BJ201 50437
65. Li XH, Qu JQ, Yi H, Zhang PF, Yi HM et al (2014) Integrated analysis of differential miRNA and mRNA expression profiles in human radioresistant and radiosensitive nasopharyngeal carcinoma cells. PLoS ONE 9(1):e87767. https://doi.org/10.1371/ journal.pone.0087767

66. Zhu M, Wang N, Tsao SW, Yuen MF, Feng Y et al (2011) Upregulation of microRNAs, miR21 and miR23a in human liver cancer cells treated with Coptidis rhizoma aqueous extract. Exp Ther Med 2(1):27-32. https://doi.org/10.3892/etm.2010.164

67. Bisognin A, Sales G, Coppe A, Bortoluzzi S, Romualdi C (2012) MAGIA(2): from miRNA and genes expression data integrative analysis to microRNA-transcription factor mixed regulatory circuits (2012 update). Nucleic Acids Res 40(Web Server issue):W13-21. https://doi.org/10.1093/nar/gks460

68. Yanai H, Ben-Shachar S, Baram L, Elad H, Gitstein G et al (2015) Gene expression alterations in ulcerative colitis patients after restorative proctocolectomy extend to the small bowel proximal to the pouch. Gut 64(5):756-764. https://doi.org/10.1136/gutjn 1-2014-307387

69. D'Argenio G, Calvani M, Casamassimi A, Petillo O, Margarucci $S$ et al (2006) Experimental colitis: decreased Octn2 and Atb0+ expression in rat colonocytes induces carnitine depletion that is reversible by carnitine-loaded liposomes. FASEB J 20(14):25442546. https://doi.org/10.1096/fj.06-5950fje

70. Miranda RC, Vetter SB, Genro JP, Campagnolo PD, Mattevi VS et al (2015) SLC6A14 and 5-HTR2C polymorphisms are associated with food intake and nutritional status in children. Clin Biochem 48(18):1277-1282. https://doi.org/10.1016/j.clinbioche m.2015.07.003

71. Durand E, Boutin P, Meyre D, Charles MA, Clement K et al (2004) Polymorphisms in the amino acid transporter solute carrier family 6 (neurotransmitter transporter) member 14 gene contribute to polygenic obesity in French Caucasians. Diabetes 53(9):2483-2486. https://doi.org/10.2337/diabetes.53.9.2483

72. Suviolahti E, Oksanen LJ, Ohman M, Cantor RM, Ridderstrale $M$ et al (2003) The SLC6A14 gene shows evidence of association with obesity. J Clin Invest 112(11):1762-1772. https://doi. org/10.1172/JCI17491

73. Corpeleijn E, Petersen L, Holst C, Saris WH, Astrup A et al (2010) Obesity-related polymorphisms and their associations with the ability to regulate fat oxidation in obese Europeans: the NUGENOB study. Obesity (Silver Spring) 18(7):1369-1377. https://doi.org/10.1038/oby.2009.377

74. Noveski P, Mircevska M, Plaseski T, Peterlin B, Plaseska-Karanfilska D (2014) Study of three single nucleotide polymorphisms in the SLC6A14 gene in association with male infertility. Balkan J Med Genet 17(2):61-66. https://doi.org/10.2478/bjmg-2014-0075

75. Smith AJP, Deloukas P, Munroe PB (2018) Emerging applications of genome-editing technology to examine functionality of GWAS-associated variants for complex traits. Physiol Genomics 50(7):510-522. https://doi.org/10.1152/physiolgenomics.00028 .2018

Publisher's Note Springer Nature remains neutral with regard to jurisdictional claims in published maps and institutional affiliations. 